\title{
вмј Global Health Healthcare leadership in Syria during armed conflict and the pandemic
}

To cite: Abbara A, Ekzayez A. Healthcare leadership in Syria during armed conflict and the pandemic. BMJ Global Health 2021;6:e005697. doi:10.1136/ bmjgh-2021-005697

Received 13 March 2021 Accepted 20 March 2021

Check for updates

(c) Author(s) (or their employer(s)) 2021. Re-use permitted under CC BY-NC. No commercial re-use. See rights and permissions. Published by BMJ.

${ }^{1}$ Department of Infection, Imperial College London, London, UK

${ }^{2}$ Syria Public Health Network, London, UK

${ }^{3}$ Conflict and Health, King's College London, London, UK

Correspondence to

Dr Aula Abbara;

a.abbara15@ic.ac.uk

\author{
Aula Abbara (1) , ${ }^{1,2}$ Abdulkarim Ekzayez ${ }^{2,3}$
}

\section{INTRODUCTION}

The COVID-19 pandemic has challenged political and healthcare leadership internationally, including in settings that have seen sustained investment and emphasis in both. Although there has been increasing recognition for the critical role of healthcare leadership, particularly by women in areas of armed conflict, ${ }^{1}$ there has yet to be effective and sustained investment with sufficient support for the development of future leaders from within cohorts of healthcare professionals. This has been particularly so among the healthcare communities in countries that have been adversely affected by protracted conflict or humanitarian crises where violence, including attacks on healthcare, has driven the forced migration of healthcare workers, limiting the pool from which medical and healthcare leaders can emerge. ${ }^{2}$ These healthcare workers may have seen sparse opportunities before the conflict to develop relevant leadership or management skills, with little attention given to these during their undergraduate or postgraduate studies. Such skill sets among healthcare workers are crucial during times of peace and more so during crises. The COVID-19 pandemic has demonstrated just how essential these skills are with requirements for flexible and capable leadership at a national or international scale, as well as more locally at a community or health facility level.

In Syria, a country that descended into conflict after violent suppression of peaceful uprisings in 2011, thousands of healthcare workers, particularly doctors, have been forcibly displaced, with many citing ongoing attacks on healthcare as a key push factor. ${ }^{2}$ Healthcare itself has been weaponised with targeted attacks continuing with impunity despite being in contravention of International Humanitarian Law. There have been almost 600 attacks on healthcare, and more than 900 healthcare workers have been killed with accusations that such attacks are

\section{Summary box}

Syria's protracted conflict has driven an exodus of healthcare workers through the weaponisation of healthcare, leaving a diminished pool from which medical and healthcare leaders can arise.

- Prior to the conflict, a lack of transparency, poor accountability and nepotism have influenced appointments to positions of power and influence in Syria, weakening such structures.

- Despite this, there has been some evidence of strong leadership in key organisations that are responding to the COVID-19 pandemic in Syria, though decades of poor investment in leadership among healthcare workers have taken their toll.

- Regional or international institutions with established medical and healthcare leadership programmes must build links to support the development of context-relevant programmes for Syria and other conflict-affected contexts.

deliberate. ${ }^{3}$ As a result, healthcare workers who remain face extreme challenges working in their health system with severe shortages of equipment, consumables and personnel while also being under attack. The COVID-19 pandemic in Syria has compounded this with the reported deaths of dozens of doctors in areas under the control of the Syrian government (currently accounting for two-thirds of the country), although the politicised nature of the response in these areas has led to accusations that the true extent of the pandemic is being suppressed. ${ }^{45}$

\section{THREATS TO MEDICAL AND HEALTHCARE LEADERSHIP IN SYRIA}

The exodus and death of healthcare workers have left a major gap in healthcare leadership across Syria, but despite these challenges faced, many healthcare workers, particularly doctors, have become leadership role models both early in the conflict and subsequently as the country descended into extreme violence. Areas outside of government control were particularly affected by violence 
with numerous hospitals rendered non-functioning. On the top of this, the withdrawal of Damascus Ministry of Health from all areas controlled by oppositions caused a huge gap in the health leadership as well as in resourcing healthcare in these areas. Doctors responded by leading the founding and running of health facilities, including underground facilities to avoid attack, and founded humanitarian organisations to respond to the needs of affected civilians. Dr Munzer Khalil, the former head of Idlib Health Directorate, explained that 'most of the medical leaders in areas outside of government control who are involved in planning and responding to the health response are practitioners without formal training in leadership however they needed to take up these roles due to gaps'. There are also leadership gaps in the health education and in the training of healthcare workers, something which could have long-term consequences for the workforce and the health system. ${ }^{6}$

After almost 10 years of conflict, Syria's health system and leadership have been fragmented, politicised and severely under-resourced. The main areas within Syria now are the north east, which is under de facto Kurdish-led Self-Administration control; the north west, which is under opposition control; areas in the north, which are under Turkish control; and the remaining two-thirds of the country, which is under the control of the Syrian government. ${ }^{5}$ Each health system has developed its own structures, governance and leadership strategies. The healthcare humanitarian response for north west Syria, an area which now contains 4.17 million people of whom 2.7 million are displaced from other parts of Syria, is led from Gaziantep in Turkey where the WHO-led health cluster is situated. ${ }^{7}$ Gaziantep is the base for dozens of international and Syrian humanitarian organisations that support the area, which is essentially besieged with, as of July 2020, a single border crossing through which health and humanitarian aid enters from Turkey. This has informed the COVID-19 response which has been technically supported by the health cluster's COVID-19 North West Syria Task Force, whereas the field response has been led by a consortium of local actors coordinated by Idlib Health Directorate (and to a lesser extent Aleppo Health Directorate), the Syria Civil Defence (the White Helmets) and other local humanitarian organisations. This unusual health governance structure for the COVID-19 response was among very limited options to lead this response in an area where at least four main different non-state armed groups dispute power and control. ${ }^{4}$ This leadership structure was able to set up subnational goals for the COVID-19 response in northwest Syria to delay the onset of the outbreak in this region through border controls and other restrictive measures. This delay strategy was fairly effective in delaying the first COVID-19 case until July 2020 compared with the areas controlled by the Syrian Government where the first case was confirmed in March $2020 .^{89}$

Despite evidence of strong leadership in some key organisations that are responding to the COVID-19 pandemic in Syria, decades of poor investment in management and leadership among healthcare professionals and potential leaders in Syria have taken their toll. Even prior to the conflict's onset, a lack of transparency, poor accountability and nepotism have influenced appointments to positions of power and influence in healthcare in Syria. Dr Naser Almhawish, a surgeon and public health specialist from Raqqa, notes that 'there was an organized and intentional government tendency to marginalise healthcare workers away from leadership or management positions; this has limited the pool from which the leaders we currently need can emerge'. An unfortunate consequence of this is the weakened state of the health system and its institutions even prior to the onset of conflict. As the health system disintegrated, particularly in areas outside of the control of the Syrian government, a gap was evident with insufficient numbers of leaders with sufficient skills and experience to take on roles in healthcare or medical leadership. Dr Khalil notes that 'leadership during the conflict and during the COVID-19 pandemic is even more challenging than in peace time and has placed more pressure on medical leaders but with almost absent governance structures for the health sector'.

\section{FEMALE LEADERSHIP IN SYRIA'S ARMED CONFLICT}

Female medical leaders face even greater challenges in their roles due to existing patriarchal social structures within Syria and increased social and religious conservatism resulting from the conflict with few given opportunities to lead. An example of a leader who overcame challenges is Dr Amani Ballour, a paediatrican whose experience as, at that time, the only female manager in an underground hospital in Eastern Ghouta was captured in the Oscar-nominated documentary The Cave which demonstrated the challenges she faced in a patriarchal society and the difficult decisions she needed to make. ${ }^{10}$ She reports that "no one in East Ghouta had sufficient experience to manage a medical facility under unprecedented and unpredictable conditions of constant bombing and attacks including the use of chemical weapons', but despite women working under these circumstances, 'many men have not abandoned this inferior view of women even in the worst conditions at all, even if she is a doctor and despite their need for her to work in light of the lack of medical staff'. She reports wanting to 'challenge the patriarchal culture and customs' through her work despite frequent criticisms, and she saw it as important for her to be a role model for other women. Role modelling as well as gender-inclusive leadership in conflict settings, particularly during the COVID-19 pandemic, is increasingly emphasised as a means through which women's representation and engagement can increase with resulting benefits of more effective regional and global responses to outbreaks of infectious diseases and reducing inequalities. ${ }^{1}$ 


\section{CONCLUSION}

For countries in protracted conflict, the consequences of the COVID-19 pandemic have been to exacerbate and expose issues of healthcare leadership, both positive and negative. As Dr Khalil explains,

after almost a decade of conflict, there are no longer excuses and we need solutions which support healthcare leadership training inside Syria-this will not only support the health system but will also stop more doctors leaving to seek such opportunities elsewhere.

One way to achieve this is for regional or international institutions with established medical and healthcare leadership programmes to support the development of context-relevant programmes that equip Syrian healthcare workers with the skills needed to lead the current and future health system in Syria.

Twitter Aula Abbara @AulaAb

Acknowledgements We would like to thank Dr Munzer Khalil, Dr Naser Almhawish and Dr Amani Ballour for their comments and quotes and Professor Richard Sullivan for his comments and review.

Contributors AA drafted the commentary and KE contributed concepts and wrote sections of the commentary. Both were involved in the editing of the commentary.

Funding AE was supported by the National Institute for Health Research (NIHR) as part of the Research for Health System Strengthening in northern Syria (R4HSSS) project reference 131207 using UK aid from the UK Government to support global health research.

Competing interests None declared.

Patient consent for publication Not required.

Provenance and peer review Not commissioned; internally peer reviewed.

Data availability statement There are no data in this work.

Open access This is an open access article distributed in accordance with the Creative Commons Attribution Non Commercial (CC BY-NC 4.0) license, which permits others to distribute, remix, adapt, build upon this work non-commercially, and license their derivative works on different terms, provided the original work is properly cited, appropriate credit is given, any changes made indicated, and the use is non-commercial. See: http://creativecommons.org/licenses/by-nc/4.0/.

\section{ORCID iD}

Aula Abbara http://orcid.org/0000-0002-7049-8399

\section{REFERENCES}

1 Meagher K, Singh NS, Patel P. The role of gender inclusive leadership during the COVID-19 pandemic to support vulnerable populations in conflict settings. BMJ Glob Health 2020;5:e003760.

2 Fouad FM, Sparrow A, Tarakji A, et al. Health workers and the weaponisation of health care in Syria: a preliminary inquiry for the Lancet-American University of Beirut Commission on Syria. Lancet 2017;390:2516-26.

3 Physicians for human rights. illegal attacks on health care in Syria, 2020. Available: https://syriamap.phr.org/\#/en

4 Ekzayez A, al-Khalil M, Jasiem M, et al. COVID-19 response in northwest Syria: innovation and community engagement in a complex conflict. J. Public Health 2020.

5 Abbara A, Rayes D, Fahham O, et al. Coronavirus 2019 and health systems affected by protracted conflict: the case of Syria. Int $J$ Infect Dis 2020;96:192-5

6 Bdaiwi $Y$, Rayes D, Sabouni A, et al. Challenges of providing healthcare worker education and training in protracted conflict: a focus on non-government controlled areas in North West Syria. Confl Health 2020;14:42.

7 Syria Public Health Network. Policy brief North West Syria: humanitarian catastrophe, 2020.

8 ReliefWeb. First COVID-19 case in North West Syria: Fears of rapid outbreak in this densely populated area - Syrian Arab Republic, 2020. Available: https://reliefweb.int/report/syrian-arab-republic/firstcovid-19-case-north-west-syria-fears-rapid-outbreak-densely

9 ReliefWeb. Syria Reports First Case of COVID-19, UOSSM Expects Parabolic Jump In Cases - Syrian Arab Republic, 2020. Available: https://reliefweb.int/report/syrian-arab-republic/syria-reports-firstcase-covid-19-uossm-expects-parabolic-jump-cases

10 The New York Times. Her dream of becoming a doctor turned into a nightmare, and a movie. Available: https://www.nytimes.com/2020/ 02/11/world/middleeast/her-dream-of-becoming-a-doctor-turnedinto-a-nightmare-and-a-movie.html 